\title{
Dental pulp mesenchymal stem/stromal cells labeled with iron sucrose release exosomes and cells applied intra-nasally migrate to intracerebral glioblastoma
}

\author{
U. ALTANEROVA ${ }^{1}$, K. BENEJOVA ${ }^{1}$, V. ALTANEROVA ${ }^{1,2}$, S. TYCIAKOVA ${ }^{2}$, B. RYCHLY ${ }^{3}$, P. SZOMOLANYI ${ }^{4}$, F. CIAMPOR ${ }^{5}$, M. CIHOVA ${ }^{2}$, V. REPISKA ${ }^{6}$, \\ K. ONDICOVA ${ }^{7}$, B. MRAVEC ${ }^{7}$, C. ALTANER ${ }^{1,2, *}$
}

${ }^{1}$ St. Elisabeth Cancer Institute, Centre for Cell Therapy and Regenerative Medicine, Bratislava, Slovakia; ${ }^{2}$ Cancer Research Institute, Biomedical Center, Slovak Academy of Sciences, Bratislava, Slovakia; ${ }^{3}$ Cytopathos, Ltd., Bratislava, Slovakia; ${ }^{4}$ Department of Biomedical Imaging and Image-guided Therapy, Medical University of Vienna, Austria; ${ }^{5}$ Institute of Virology, Biomedical Center, Slovak Academy of Sciences, Bratislava, Slovakia; ${ }^{6}$ Institute of Medical Biology, Genetics and Clinical Genetics, Faculty of Medicine, Comenius University in Bratislava, Slovakia; ${ }^{7}$ Institute of Pathophysiology, Faculty of Medicine, Comenius University in Bratislava, Slovakia

${ }^{*}$ Correspondence: exonalt@savba.sk

Received May 2, 2016 / Accepted June 9, 2016

\begin{abstract}
We report on a simple iron oxide (Venofer) labeling procedure of dental pulp mesenchymal stem cells (DP-MSCs) and DPMSCs transduced with yeast cytosinedeaminase::uracilphosphoribosyltransferase (yCD::UPRT-DP-MSCs). Venofer is a drug approved for intravenous application to treat iron deficiency anemia in patients. Venofer labeling did not affect DP-MSCs or yCD::UPRT-DP-MSCs viability and growth kinetics. Electron microscopy of labeled cells showed internalized Venofer nanoparticles in endosomes. MRI relativity measurement of Venofer labeled DP-MSCs in a phantom arrangement revealed that 100 cells per $0.1 \mathrm{ml}$ were still detectable. DP-MSCs or yCD::UPRT-DP-MSCs and the corresponding Venofer labeled cells release exosomes into conditional medium (CM). CM from yCD::UPRT-DP-MSCs in the presence of a prodrug 5-fluorocytosine caused tumor cell death in a dose dependent manner. Iron labeled DP-MSCs or yCD::UPRT-DP-MSCs sustained their tumor tropism in vivo; intra-nasally applied cells migrated and specifically engrafted orthotopic glioblastoma xenografts in rats.
\end{abstract}

Key words: dental pulp MSCs, iron labeling, yCD::UPRT-exosomes, intranasal application, migration to intracerebral glioblastoma

Mesenchymal (stromal) stem cells (MSCs) can be readily isolated from human tissues like bone marrow, adipose, umbilical cord, dental pulp and others. MSCs represent novel promising therapeutic tools of emerging regenerative medicine. MSCs of different origin are tested in large number of clinical trials for treatment of diseases, which do not have at present adequate therapy. As of July 2016, the public clinical trials database showed 627 clinical trials using MSCs for a very wide range of therapeutic applications [1]. It has been increasingly observed that the transplanted MSCs did not necessarily engraft and differentiate at the site of injury but might exert their therapeutic effects through paracrine manner inducing endogenous reparatory processes. It has been recognized that MSCs released rich secretome together with extracellular exosomes that might be responsible at least to some degree for transfer of regulatory gene products needed for reparatory processes induction [2].
The therapeutic potential of MSCs-derived extracellular vesicles was recently comprehensively reviewed [3].

Dental pulp derived mesenchymal stem cells (DP-MSCs) are known for the high proliferative potential for self-renewal, plasticity and multipotential capabilities. Dental pulp is made of ecto-mesenchymal elements, containing neural crestderived cells. DP-MSCs are intensively studied because of their neural characteristics being considered as cells for the peripheral neural regeneration [4]. Our comparison of DP-MSCs with bone marrow and adipose tissues derived MSCs revealed differences in the expression of pluripotent stem cells genes that reflected ecto-mesenchymal origin of DP-MSCs [5].

MSCs engineered to express therapeutic gene products are becoming more promising in cancer therapy for their ability to selectively target tumor cells. Their administration in animal models resulted in successful inhibition of growth of variety 
of tumors, regardless of tumor kind [6]. Prodrug gene therapy for cancer therapy mediated by mesenchymal stem/stromal cells engineered to express yeast cytosinedeaminase::uracilp hosphoribosyltransferase (yCD::UPRT) is at present the most efficient experimental gene therapeutic system for cancer [7]. The ability of yCD::UPRT-expressing adipose tissue derived mesenchymal stem cells (AT-MSCs) to convert the relatively non-toxic 5-fluorocytosine (5-FC) into the highly toxic antitumor drug 5-fluorouracil (5-FU) along with their ability to home to tumor sites and micrometastases, makes these cells designated therapeutic stem cells (ThSCs) an unique tool to convert prodrugs to cytotoxic drugs directly within the tumor mass thus avoiding systemic toxicity. Prodrug administration not only eliminates tumor cells, but consequently kills the more resistant ThSCs as well [8-10]. Furthermore, we have shown that human AT-MSCs or bone marrow derived mesenchymal stem cells (BM-MSCs) transduced with suicide gene have the ability to track and engraft into glioblastoma with positive therapeutic outcome $[11,12]$.

Tumor tracking ability of mesenchymal and neural stem cells to brain was proved in the experiments with MSCs labeled with superparamagnetic iron oxide nanoparticles [13, 14]. Tumor tropism of AT-MSCs genetically modified with suicide gene was sustained as we demonstrated it with labeling them with poly(L-lysine)-modified superparamagnetic iron oxide nanoparticles [11].

In this study, we explored, by in vitro and in vivo investigations, a safe and effective protocol for Venofer labeling of DP-MSCs and DP-MSCs transduced with suicide gene. Labeling procedure is using three clinically approved drugs: Venofer, heparin and protamine sulphate that could facilitate the rapid translation of this technique to clinical trials. We examined exosomes released from DP-MSCs stably transduced with yCD::UPRT-fused gene and labeled with Venofer for their ability to kill tumor cells. The broader additional objective of the current study was to develop a safe, non-invasive and effective strategy to monitor tumors and metastases by MRI and to examine glioblastoma tropism of the iron oxide labeled DP-MSCs intranasally applied.

\section{Materials and methods}

DP-MSCs culture isolation and maintenance. All donors of tissue specimens used for isolation and propagation of MSCs were informed about the nature of the study and pro-

Table 1. Labeling schemes of DP-MSCs with Venofer

\begin{tabular}{cccc}
\hline $\begin{array}{c}\text { Venofer } \\
\mu \mathrm{g} / \mathrm{ml}\end{array}$ & $\begin{array}{c}\text { Protamine sulphate } \\
\mu \mathrm{g} / \mathrm{ml}\end{array}$ & $\begin{array}{c}\text { Heparin } \\
\mathrm{IU} / \mathrm{ml}\end{array}$ & Corresponding picture \\
\hline 200 & 10 & 0 & 1 \\
200 & 10 & 2 & 2 \\
400 & 10 & 0 & 3 \\
400 & 10 & 2 & 4 \\
1000 & 0 & 0 & 5 \\
\hline
\end{tabular}

vided their written informed consent. Dental pulp stem cells (DP-MSCs) were isolated from dental pulp tissue fragments adhered to plastic tissue culture dishes [5]. For expansion the cells were seeded at 4000 cells $/ \mathrm{cm}^{2}$ to plastic dishes (Corning Life Sciences) and grown with medium exchange every 2-3 days. Adherent cells were split after reaching confluence with $0.05 \%$ trypsin/EDTA (Difco). DP-MSCs used for the experiments were up to fifth passage or less. Cell cultures were grown in a complete culture medium DMEM low glucose $(1 \mathrm{~g} / \mathrm{L})$ supplemented with $4 \%$ human platelet extract (PE), antibiotic antimycotic solution (Gibco Life Technologies) and incubated at $37{ }^{\circ} \mathrm{C}$ in humidified atmosphere with $5 \% \mathrm{CO}_{2}$. The cells were frozen in $1 \mathrm{ml}$ aliquots in liquid nitrogen suspended at $10 \times 106$ cells $/ \mathrm{ml}$ in medium containing $10 \%$ dimethylsulfoxide and $10 \%$ human serum albumin.

Preparation of DP-MSC expressing yCD::UPRT gene. DP-MSCs with yCD::UPRT gene (therapeutic stem cells) were prepared with the same procedure as described previously for the adipose tissue derived MSCs [8]. Briefly, subconfluent cultures of DP-MSCs were transduced thrice in 3 consecutive days with virus-containing medium from GP+envAM12/ pyCD::UPRT cells supplemented with $5 \mu \mathrm{g} / \mathrm{ml}$ protamine sulfate. Transduced cells were selected for resistance to G-418 $(0.4 \mathrm{mg} / \mathrm{ml})$.

The therapeutic stem cells were expanded in low glucose ( 1 g/l) DMEM supplemented with 4\% PE. Rat glioblastoma C6 cells were cultured in high glucose DMEM supplemented with $5 \%$ FCS and an antibiotic-antimycotic mix (Life Technologies) in a humidified atmosphere and $5 \% \mathrm{CO}_{2}$ at $37^{\circ} \mathrm{C}$.

Labeling of mesenchymal stem cells with Venofer. Labeling procedure used resulted from small modifications of the labeling approach described by others $[13,14,23]$. The variations of three concentrations of Venofer $(200,400,1000 \mu \mathrm{g} / \mathrm{ml})$ with protamine sulphate $(10 \mu \mathrm{g} / \mathrm{ml})$ and heparin) $(2 \mathrm{IU} / \mathrm{ml})$ were tested to optimize the labeling. The combinations are presented in Table 1. At first, heparin and protamine sulphate were mixed together to form a stable complex. Then final labeling complex was created by adding Venofer to already prepared stable complex in PE-free culture media at room temperature. The labeling complex was added to MSCs plated to dishes 24 hours ahead and incubated ( 4 hours, $37^{\circ} \mathrm{C}, 5 \% \mathrm{CO}_{2}$ ). The culture medium was supplemented with $4 \%$ of $\mathrm{PE}$ as a growth supplement and the cells were incubated overnight $\left(37^{\circ} \mathrm{C}, 5 \% \mathrm{CO}_{2}\right)$. After 24 hours, MSCs were washed first with DMEM only, then with DMEM containing heparin $(10 \mathrm{U} / \mathrm{ml})$ and finally PE free medium was added for 24 hours to obtain CM. Venofer labeled DP- MSCs for animal applications were trypsinized, centrifuged, and resuspended in PBS for intranasal applications.

Assessment of cell viability and growth rate by IncuCyte live cell monitoring system. Cell growth was monitored by "real time in vitro micro- imaging" using the IncuCyte $\mathrm{ZOOM}^{\mathrm{mm}}$ Kinetic Imaging System. The IncuCyte system allows for the hourly monitoring of cell growth by determining the confluence of cells and displaying morphologic changes associated with treatment. 
Differentiation of DP-MSCs in vitro. The ability of MSCs to differentiate to adipocytes, osteoblasts and chondrocytes was evaluated using Human Mesenchymal Stem Cell Functional Identification Kit (R\&D SYSTEMS Minneapolis, MN 55413). Protein concentration was measured by Pierce ${ }^{\mathrm{Tw}} \mathrm{BCA}$ Protein Assay Kit (Thermo SCIENTIFIC) according to the manufacturer's instructions.

Prussian blue staining for Venofer nanoparticle-labeled DP-MSCs and glioblastoma slices. Prussian blue staining was performed using the Accustain iron stain kit (SigmaAldrich, St. Louis, MO, http://www.sigmaaldrich.com) according to the manufacturer's protocol. Venofer-labeled MSCs were washed with PBS to remove any free Venofer nanoparticles. Smears of cells on glass slides or cells in Petri dishes were fixed for 10 minutes using $4 \%$ paraformaldehyde (Sigma-Aldrich). Samples were then washed three times in deionized water and incubated with Pearls' reagent (4\% potassium ferrocyanide $/ 12 \% \mathrm{HCl}, 1: 1 \mathrm{vol} / \mathrm{vol}$ ) for 10 minutes at room temperature. Samples were observed by an inverted optical microscope. For each MSCs, the comparative labeling efficiency of each concentration of Venofer (expressed in $\mu \mathrm{g}$ of Fe) was assessed visually. The similar labeling protocol (40 minutes under agitation) was used to stain brain sections obtained from rats. Glioblastoma sections were dehydrated through graded alcohols and mounted with Eukitt (O. Kindler $\mathrm{GmbH} \& \mathrm{Co}$ ).

Electron microscopy analysis. The MSCs labeled with complex of Venofer nanoparticles, were replaced in Venoferfree growth medium, the samples were harvested, washed with PBS and centrifuged ( $180 \mathrm{x} \mathrm{g}, 15 \mathrm{~min})$. The pellet was fixed using $4 \% \mathrm{PFA}+2 \%$ glutaraldehyde in $50 \mathrm{mM}$ cacodylate buffer for 15 minutes at RT. Samples were washed three times with PBS and postfixed in 2\% osmium tetroxide for $90 \mathrm{~min}$ on ice. After further washing with water the cells were stained overnight in an aqueous solution of uranyl acetate (0.5\%), dehydrated through graded alcohols and embedded in epoxy resin (EPON; Miller-Stephenson Chemical Company). Ultrathin sections were analyzed with a transmission electron microscope (JEOL, Japan).

MRI and relaxometry studies on Venofer-labeled DPMSCs. For phantom relaxometry studies, $500 \mu \mathrm{L}$ of cell suspension $\left(5 \times 10^{5}\right.$ Venofer-labeled or unlabeled control cells in PBS) were mixed to an equal volume of gelatin (8\% $\mathrm{w} / \mathrm{w}$ ) in plastic dishes (area: $2 \mathrm{~cm}^{2}$ ), to obtain cell suspension dispersion. In order to obtain T2 relaxometry (R2), spinechomultiecho sequence (TR 2.500, thickness $1 \mathrm{~mm}$ ) with 8 echo times ranging between 50 and 400 milliseconds (ms) was acquired and reconstructions of T2 maps were obtained by interpolating the signal curve for different echo times. Sample was prepared in the Petri dish of $38 \mathrm{~mm}$ in diameter. The dish was filled with the $2 \%$ agarose in a layer of about 2 $\mathrm{mm}$. During agarose cooling phase small cavities were made into the agarose gel using bottom part of a small Eppendorf tube. These cavities served as a nest for Venofer-labeled DP-MSCs and were subsequently filled with the suspension of Venofer-labeled DP-MSCs and covered by second $2 \mathrm{~mm}$ thick agarose layer. The 7Tesla whole body Siemens scanner (Siemens Healthcare, Erlangen, Germany) was used for measurements. In order to increase image resolution, microgradient insert was placed into the center of the whole body scanner. Microgradient insert is capable to provide 750 $\mathrm{mT} / \mathrm{m}$ magnetic field gradients, which allows to perform MR experiment with image resolution of $180 \mu \mathrm{m} \times 180 \mu \mathrm{m}$ and $2 \mathrm{~mm}$ slice thickness.

Concentration of exosomes by ultracentrifugation and gene expression analysis. Cell conditional medium freed from cell debris by sequential centrifugation was passed through $0.22 \mu \mathrm{M}$ syringe filter and centrifuged at $150.000 \mathrm{xg}$ for 14 hours. Sediment was washed with PBS and resuspended by intensive Vortexing. Gene analysis was performed by standard PCR technique using primers previously described (8). Total RNA was isolated by TRIzol reagent (Gibco). For PCR Phire Hot Start II DNA polymerase (Thermo Fisher Scientific) was used. RNA was reverse transcribed with SensiFAST cDNA Synthesis Kit (Bioline. Electrophoretic separation was performed in 4\% MetaPhor agarose gel (Lonza) in TAE buffer. GeneRuler 50 bp DNA Ladder (Thermo Fisher Scientific) served as a size comparison tool.

Animal experiments. Adult male $\mathrm{CD}^{\circledR} \mathrm{IGS}$ rats purchased from Charles River were used for in vivo experiments in accordance with institutional guidelines under the approved protocols. In all experiments the rats were anaesthetized with an intramuscular injection of a mixture containing ketamine (Narkamon 5\% - $1.2 \mathrm{ml} / \mathrm{kg} \mathrm{bw}$ ) and xylazine (Rometar 2\% $0.4 \mathrm{ml} / \mathrm{kg} \mathrm{bw}$ ) before the surgical procedures. A dose of $5 \times 10^{5}$ C6 cells injected by a stereotaxic technique was chosen for all experiments to guarantee quick onset of tumor growth. Animals were inspected every day for their behavior and body weights. Animals with excessive weight loss and uncoordinated behavior were euthanized and their brains were analyzed histopathologically.

Stereotaxic intracerebral implantation of glioblastoma cells. Freshly prepared C6 cell suspensions in PBS was injected with a stereotaxic apparatus (David-Kopf Instruments). The selected stereotaxic coordinates for C6 cells were chosen according to Paxinos and Watson 23 and were as follows: anteroposterior: $0.0 \mathrm{~mm}$; medio-lateral: $3.0 \mathrm{~mm}$; vertical: $-6.0 \mathrm{~mm}$. Cell suspension was slowly injected in $5 \mu \mathrm{L}$ volume of PBS over a five-minute period using a Hamilton syringe. The needle was left in place for 2 minutes and then slowly elevated for 3 minutes.

Statistical analysis. Statistical comparisons of groups were performed using the Student's t-test. Statistical significance: ${ }_{* * *} \mathrm{P}$ value was $\leq 0.001$.

\section{Results}

Characterization of Venofer nanoparticles. Measurements of Venofer suspension in PBS revealed that Venofer nanoparticles are of round morphology. They have a char- 


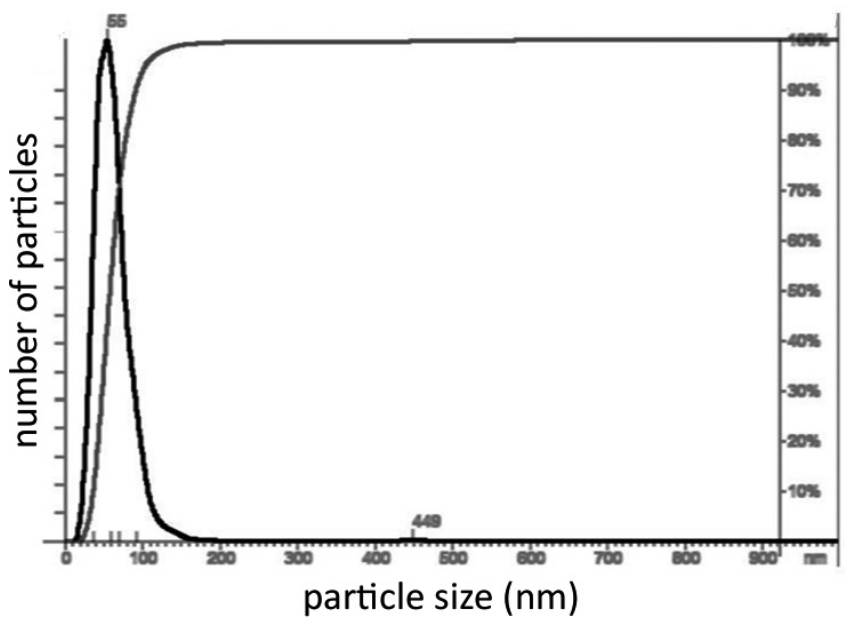

Figure 1. Characterization of Venofer nanoparticles by Nanosight.

acter of highly homogenous nanoparticles with mean peak diameter of $65 \mathrm{nM}$. The nanoparticles concentration of the commercial drug measured by Nanosight was $8.75 \times 10^{13}$ particles/ml (Figure 1).

Labeling of DP-MSCs with Venofer. The labeling was performed as described in Materials and Methods section. Several combinations of Venofer, with protamine sulphate and heparin were tested as listed in Table 1. Labeling intensity was Venofer dose dependent. The highest Venofer concentration $(1000 \mu \mathrm{g} /$ $\mathrm{ml}$ ) was only slightly toxic to DP-MSCs. The cells labeled with $400 \mu \mathrm{g} / \mathrm{ml}$ Venofer in combination with protamine sulphate and/or heparin lead to optimally labeled cells with a viability reaching 98\%. Venofer-labeled DP-MSCs morphologically did not differ from their parental cells. Figure 2 shows the morphology of Venofer-labeled DP-MSCs stained for Fe by Prussian blue. The labeled cells can be kept by trypsinization for at least 10 passages without any signs of senescence, but the number of Venofer nanoparticles in the cells diminished with increasing number of passages.

Characterization of Venofer-labeled DP-MSCs by differentiation and by cell surface markers. To asses multipotency, Venofer-labeled MSCs and unlabeled control cells were plated in differentiation media and the differentiation capability was compared to MSCs isolated from adipose tissue and bone marrow (Figure 3). It was found that DP-MSCs as well as the Venofer-labeled cells can be induced to osteogenic and chondrogenic differentiation lineages but not to adipogenic lineage. Under the same conditions BM-MSCs and AT-MSCs can be induced to all three differentiation lineages required for MSCs characterization in vitro. Interestingly, while BM-MSCs and AT-MSCs showed a gradual loss of osteogenic differentiation potential with increasing number of passages in vitro, DP-MSCs on the other hand had an increasing osteogenic potential. DPMSCs and yCD::UPRT-DP-MSCs were positive for CD44, CD73, CD90 and CD105 markers and negative for CD45 and CD34 similarly as we described previously for AT-MSCs [8]. The Venofer labeling did not change this behavior.

Intracellular iron localization measurement. Analysis of ultrathin sections of Venofer-labeled DP-MSCs by transmission electron microscopy revealed that Fe-nanoparticles are localized in cell cytoplasm only (Figure 4).

Cell viability of Venofer-labeled DP-MSCs and yCD:: UPRT-DP-MSCs. Figure 5 shows growth curves of Venofer la-

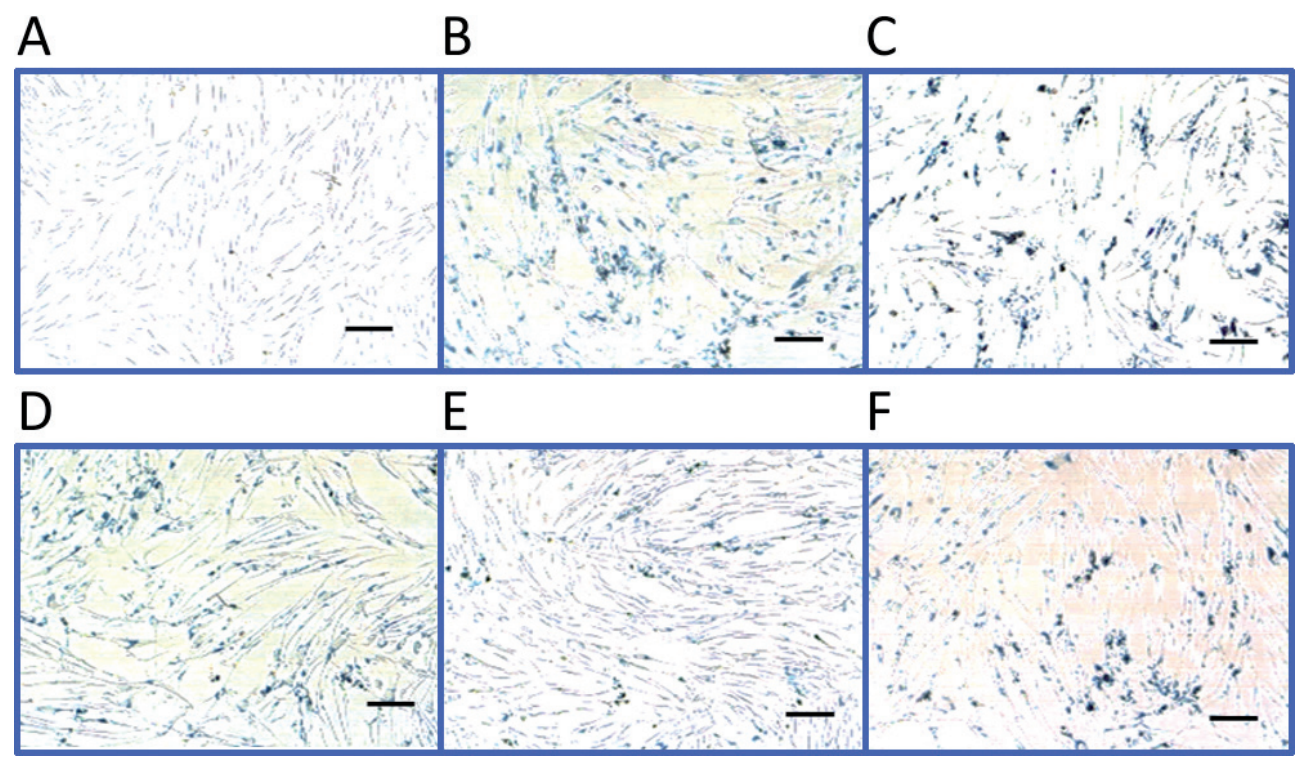

Figure 2. Morphology of Venofer-labeled DP-MSCs with various combinations of labeling procedure. Cells were stained by Prussian blue. (A); Control cells; (B);Venofer $200 \mu \mathrm{g} / \mathrm{ml}$, protamine sulphate $10 \mu \mathrm{g} / \mathrm{ml}$; (C); Venofer $200 \mu \mathrm{g} / \mathrm{ml}$, protamine sulphate $10 \mu \mathrm{g} / \mathrm{ml}$, heparin $0.4 \mathrm{IU} / \mathrm{ml}$; (D); Venofer $400 \mu \mathrm{g} / \mathrm{ml}$, protamine sulphate $10 \mu \mathrm{g} / \mathrm{ml}$; (E); Venofer $400 \mu \mathrm{g} / \mathrm{ml}$, protamine sulphate $10 \mu \mathrm{g} / \mathrm{ml}$, heparin $0.4 \mathrm{IU} / \mathrm{ml}$; (F); Venofer $1000 \mu \mathrm{g} / \mathrm{ml}$. 

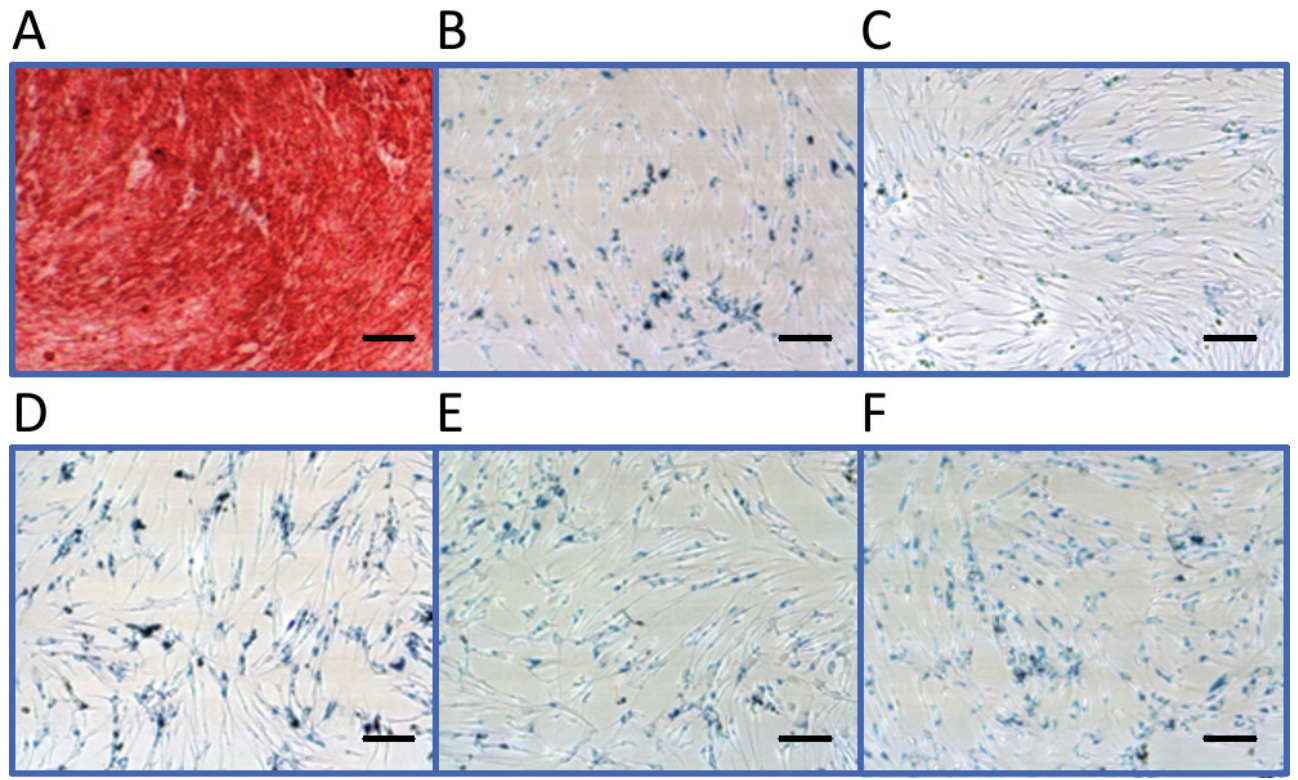

Figure 3. Differentiation of Venofer-labeled DP-MSCs stained for Fe. Pictures of DP-MSCs/Fe induced to osteogenic and adipogenic differentiation and corresponding cells, both stained by Prussian blue. (A); DP-MSC osteogenic differentiation (B); DP-MSCs (C); DP-MSC adipogenic differentiation (D); DP-MSC (Fe) osteogenic differentiation (E); DP-MSC (Fe) osteogenic differentiation stained for Fe (F); DP-MSC (Fe) stained for Fe.

beled DP-MSCs compared with the corresponding naive cells. A combination of heparin, protamine sulphate, and Venofer did not affect cell viability and growth kinetics of both types of cells significantly. The growth of the Venofer labeled cells
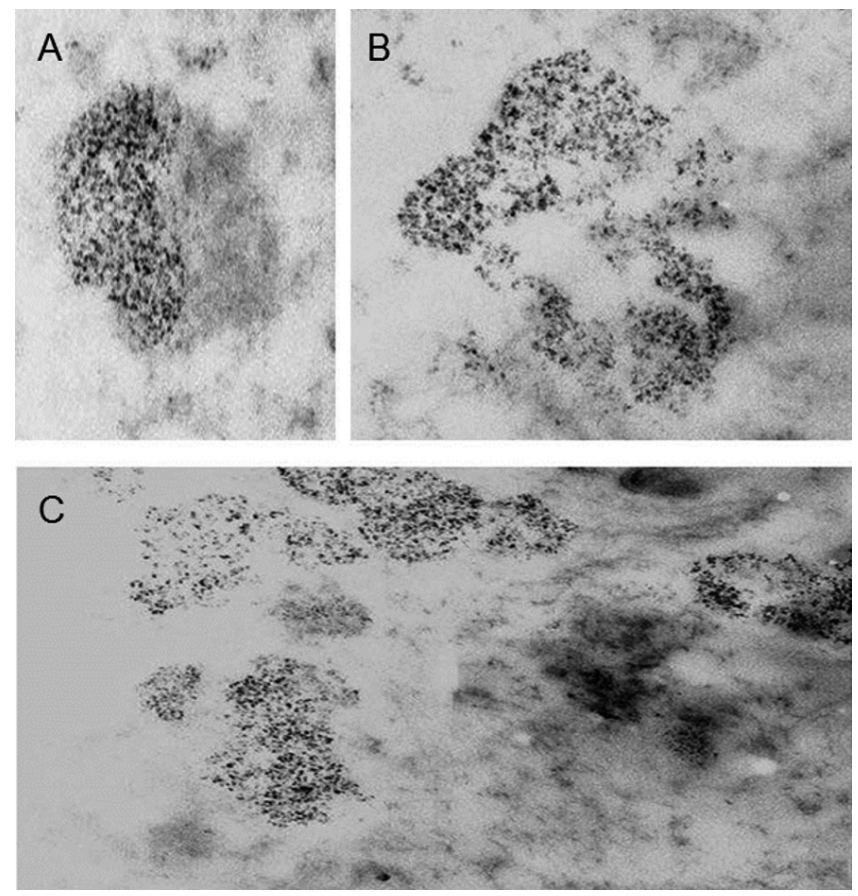

Figure 4. Pictures of ultrathin sections of the Venofer-labeled DP-MSCs obtained by the transmission electron microscopy $(\mathrm{A}, \mathrm{B}, \mathrm{C})$. was a little bit slower compared to the same naïve cells. The difference in time the cells reached the saturation density was 24 hours during 5 days incubation period (Figure 5).

DP-MSCs, yCD::UPRT-DP-MSCs and Venofer labeled cells release exosomes. Recently we and others demonstrated that human MSCs release exosomes, possessing stimulating or inhibiting tumor cell growth activity depending on the MSC tissue origin and type of the tumor cells [2,7]. We proved that DP-MSCs or yCD::UPRT-DP-MSCs and the corresponding

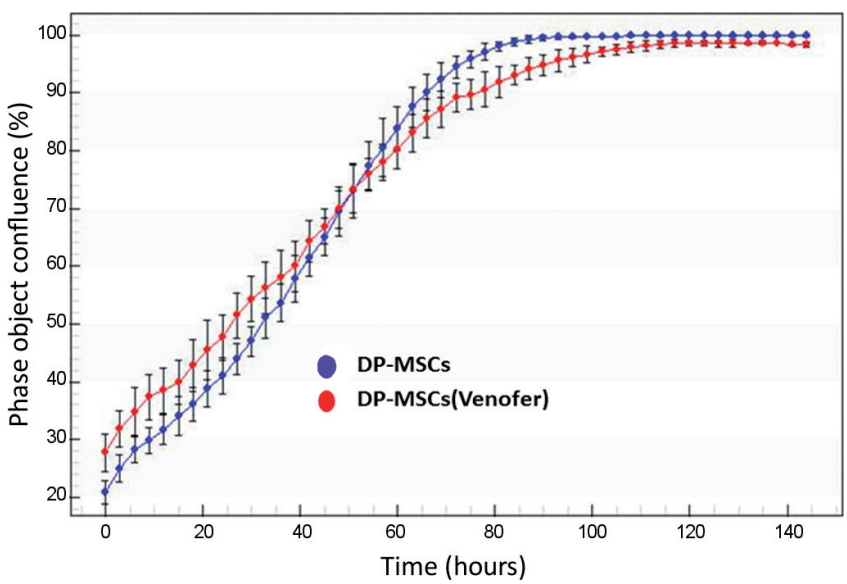

Figure 5. Growth curves of Venofer labeled DP-MSCs and corresponding naive cells monitored by real time in vitro imaging in undisturbed cultures using the Incucyte system. The cell density was followed by image scanning of the culture every 2 hours during 6 days. For each scan the standard deviation was calculated. 


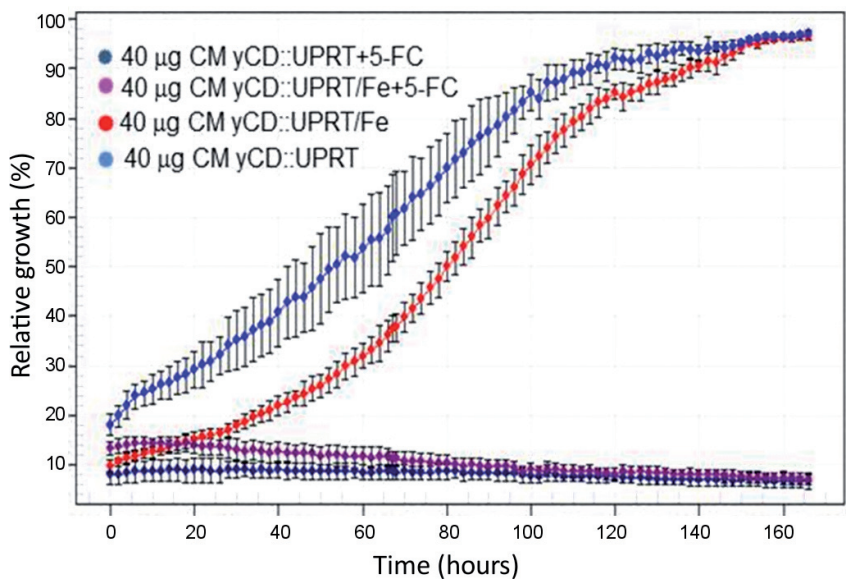

Figure 6. Growth curves of PC 3 cells treated with CM from yCD::UPRTDP-MSCs in presence and/or absence of 5-FC. PC3 cells $\left(3 \times 10^{3}\right)$ were plated in wells of the 96 well plate. Next day, $40 \mu \mathrm{g} \mathrm{CM}$ protein was added to growth medium in each well either with prodrug 5-FC or without 5-FC. The course of growth/inhibition was monitored by the Incucyte system under the same conditions as in figure 5 .

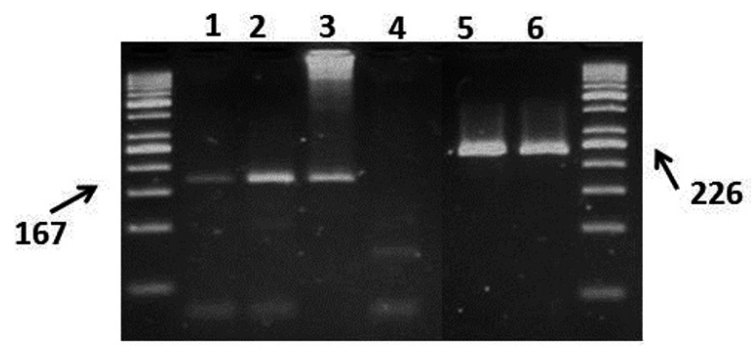

$$
\begin{aligned}
& \text { 1 - CM yCD::UPRT-DP-MSCs } \\
& \text { 2-- exosomes yCD::UPRT-DP-MSCs } \\
& \text { 3-- yCD::UPRT plasmid } \\
& \text { 4- NTC } \\
& \text { 5, 6- GAPDH }
\end{aligned}
$$

Figure 7. Detection of yCD::UPRT mRNA by PCR in exosomes released from yCD::UPRT-DP-MSCs cells.

Venofer labeled cells release exosomes in the conditional medium (CM).

CM with exosomes from yCD::UPRT-DP-MSCs and corresponding Venofer-labeled cells internalized tumor cells and in the presence of 5-FC caused their death in a dose dependent manner (Figure 6).

MSC-yCD-UPRT cells release exosomes with coding mRNA. In order to see what was responsible for tumor cell killing activity in the CM, we concentrated exosomes by ultracentrifugation and inspected the sediment for presence of yCD::UPRT m-RNA. We isolated total RNA, treated with DNase I, reverse transcribed and analyzed by PCR by agarose gel electrophoresis. As shown in Figure 7, we detected the yCD::UPRT mRNA in the exosome's cargo. Therefore exo-
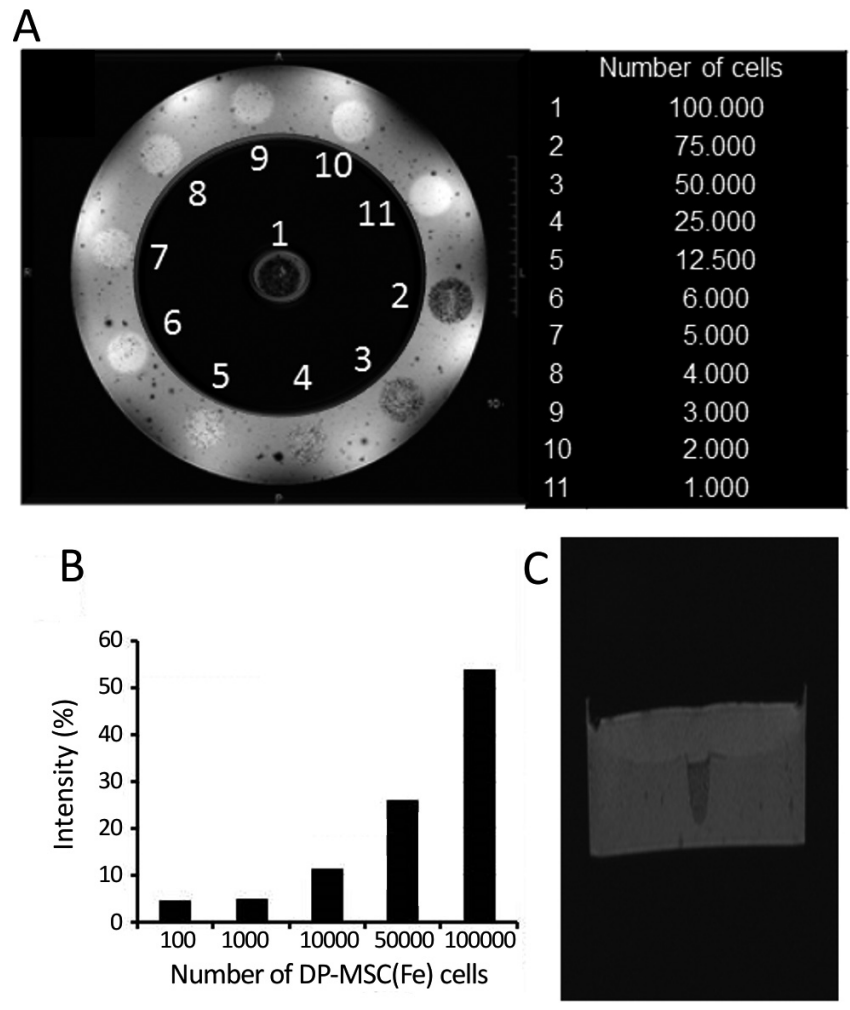

Figure 8. Magnetic resonance imaging and in vitro MRI relativity measurement. (A); Picture of phantom with different number of Venofer labeled DP-MSCs; (B); Graph of relationship between number of Fe-labeled DPMSCs (DP-MSCs/Fe) and color intensity evaluated by ImageJ software; (C); MRI image in a transversal orientation shows bottom and top agarose layers and central cavity (cavity number 1 in picture $A$ ) filled with the suspension of DP-MSCs/Fe.

somes internalized in tumor cells acted through translation of yCD::UPRT mRNA to enzyme converting 5-FC to 5-FU.

Magnetic resonance imaging and in vitro $\mathrm{MRI}$ relativity measurement. In order to see what the minimal number of Venofer labeled cells could be visualized by MRI machine (3Tesla and 7Tesla whole body human scanner equipped with microgradient insert), we tested it in a phantom arrangement. MRI relativity measurement of Venofer labeled DP-MSCs revealed that 100 cells per $0.1 \mathrm{ml}$ are still detectable (Figure 8).

Intranasal administration of Venofer-labeled human DPMSCs to intracerebral rat glioblastoma C6. In order to see whether DP-MSCs could penetrate and be tracked in the brain after intranasal administration we used rats bearing glioblastoma C6 cells stereotaxically implanted into brain. A dose of $5 \times 10^{5}$ C6 cells caused death in all animals in 15-30 days. Fourteen days after tumor cells administration, Venoferlabeled DP-MSCs $\left(6 \times 10^{6}\right)$ were applied in the nasal cavity of both control and tumor bearing rats. The brains of rats with glioblastoma were removed at different hours after intranasal administration and examined by histological staining for iron labeled cells. Figure 9 shows the presence of Prussian blue 


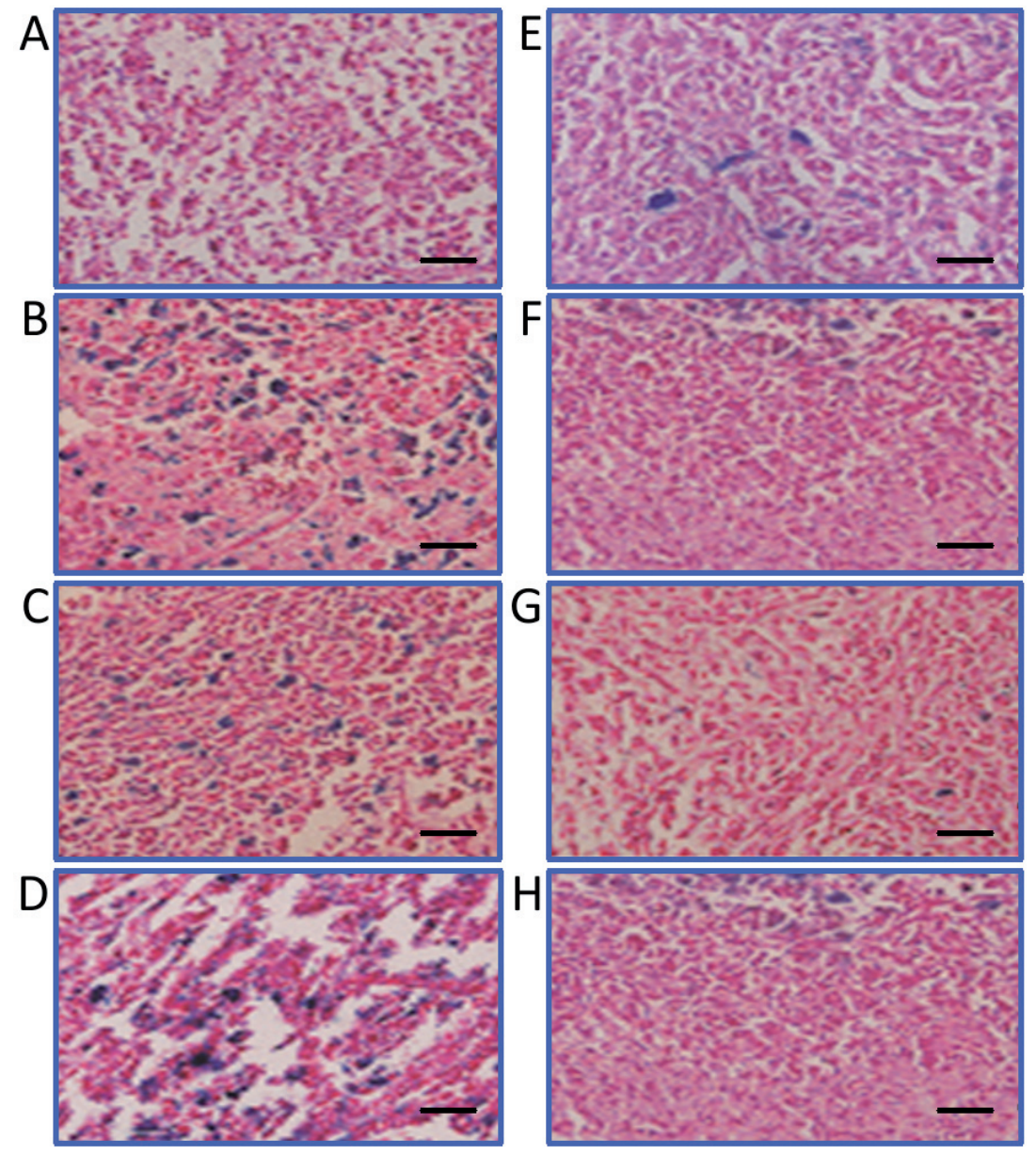

Figure 9. Migration of DP-MSC/Fe applied intranasal to intracerebral glioblastoma. Pictures of histological slices of rat glioblastoma stained for Fe. Brains were obtained at different time after intranasal application of Venofer labeled DP-MSCs. (A); Control, (B); 1 hour, (C); 2 hours, (D); 72 hours, (E); 120 hours, (F); 168 hours, (G); 168 hours, (H); 240 hours. The scale bars in pictures are $50 \mu \mathrm{m}$.

stained cells in glioblastoma slices up to 10 days after intranasal administration. None stained cells were detected in control, non-tumor bearing animals, or PBS treated animals. Obtained data show that DP-MSCs labeled with Venofer are capable of rapid penetration into the brain of rats bearing glioblastoma after intranasal inoculation thus confirming tumor tracking capability of MSCs generally.

\section{Discussion}

MSCs possess the ability to migrate to the site of injury and secrete a variety of factors capable of a number of functions inducing and supporting regenerative processes in the damaged tissue. Rich MSCs's secretome together with released exosomes participate on the paracrine cross-talk between cells leading to biological consequences [15]. The exosomes being able to bring into the cell their cargo composed from biologically active compounds like micro RNA, m-RNA, mitochondrial DNA, etc. play very likely a crucial role in the induction of endogenous reparatory process leading, for instance, to induction of angiogenesis, protection from apoptotic cell death and in a concord with biologically active proteins of the secretome to a modulation of the immune system. The idea of trans-differentiation of injected MSCs to the required cell type at the defect site does not have sufficient experimental support.

DP-MSCs reflecting their cranial neural crest origin, slightly differ from bone marrow or the adipose tissue MSCs [5]. Our observation of the ability of DP-MSCs, unlike AT-MSCs, to support induction of osteogenic differentiation despite the large number of passages in vitro is in a good agreement with our earlier finding of higher expression of E-cadherin and lower expression of Snail gene, molecular paths of the reparative functions where EMT plays an important role. DP-MSCs behavior obviously contributed to the repair of alveolar bone defect in all patients in clinical trial finished recently [16].

Neurotropic property of DP-MSCs favors them for treatment of large number of neural diseases in the regenerative 
medicine [17]. Neurotropic properties of dental pulp MSCs certainly might further facilitate the glioma migration ability of MSCs to brain malignancies [18, 19]. We found that intranasal application of DP-MSCs lead to engrafted Venofer-labeled DP-MSCs in intracranial rat glioblastoma. In addition, human DP-MSCs genetically modified with yeast uracilphosphoribosyltransferase release exosomes able to invade tumor cells and kill them in presence of prodrug 5-FC, contributing thus to the high therapeutic efficacy of the CDy-AT-MSCs/5-FC system [12]. Our results are in agreement with a previous report showing penetration MSCs in the brain after intranasal application in rats. Intranasal delivery of stem cells seems to be a promising noninvasive route to deliver neural stem/progenitor cells to the brain in attempts to treat ischemic brain damage or to target intracerebral glioma [20].

Tumor tropism of Fe labeled MSCs can be used for MRI tracking. In phantom model we found that 100 Venofer labeled MSCs per $0.1 \mathrm{~mL}$ are detectable by MRI. J. T. Rosenberg et al. [21] have shown that transplantation of the human MSCs labeled with $\mathrm{Fe}$ showed excellent retention of contrast in stroke-induced rats proving their stability for long-term MRI detection. Very recently iron sucrose labeled human MSCs were evaluated for cell therapeutic applications after transplantation into lapine intervertebral discs [22]. The results indicate that iron sucrose can be used as a cell tracer with a stable histological detection potential [23]. Furthermore, recently it was shown that the therapeutic regenerative potential of MSCs, being realized mainly through paracrine fashion, can be potentiated by iron nanoparticles. Iron oxide nanoparticlemediated development of cellular gap junction crosstalk to improve MSCs therapeutic efficacy for myocardial infarction [24].In summary, we report broad therapeutic and diagnostic usefulness of iron oxide labeled DP-MSCs and suicide gene transduced DP-MSCs. In addition exosomes released from these cells represent promising biomedical products that could substitute cells in the future.

Acknowledgments:The study was supported by grant awarded to CA by the League against Cancer.

\section{References}

[1] ClinicalTrials.gov. A service of the U.S. National Institutes of Health. Available from: https://clinicaltrials.gov/ct2/show, access date 12-07-2016.

[2] BAGLIO SR, ROOIJERS K, KOPPERS-LALIC D, VERWEIJ FJ, PEREZ LANZON $M$ et al. Human bone marrow- and adipose-mesenchymal stem cells secrete exosomes enriched in distinctive miRNA and tRNA species. Stem Cell Res Ther 2015; 6: 127. http://dx.doi.org/10.1186/s13287-015-0116-Z

[3] RANI S, RYAN AE, GRIFFIN MD, RITTER T. Mesenchymal Stem Cell-derived Extracellular Vesicles: Toward Cell-free Therapeutic Applications. Mol Ther 2015; 23: 812-823. http:// dx.doi.org/10.1038/mt.2015.44
[4] MARTENS W, BRONCKAERS A, POLITIS C, JACOBS R, LAMBRICHTS I. Dental stem cells and their promising role in neural regeneration: an update. Clin Oral Investig 2013; 17: 1969-1983. http://dx.doi.org/10.1007/s00784-013 $\underline{-1030-3}$

[5] STANKO P, KAISEROVA K, ALTANEROVA V, ALTANER C. Comparison of human mesenchymal stem cells derived from dental pulp, bone marrow, adipose tissue, and umbilical cord tissue by gene expression. Biomed Pap Med Fac Univ Palacky Olomouc Czech Repub 2014; 158: 373-377.

[6] ALTANER C. Stem Cell-Mediated Prodrug Gene Therapy of High-Grade Brain Tumors, pp 57-72. In: K. Shah (Eds.), Stem Cell Therapeutics for Cancer, Wiley-Blackwell, 2013, pp 304. ISBN 978-1-118-28242-7.

[7] ALTANER C. Prodrug gene therapy for cancer mediated by mesenchymal stem/stromal cells engineered to express yeast cytosinedeaminase::uracil phosphoribosyltransferase. J Stem Cell Res Ther 2015; 5: 2157-7633. http://dx.doi. org/10.4172/2157-7633.1000264

[8] KUCEROVA L, ALTANEROVA V, MATUSKOVA M, TYCIAKOVA S, ALTANER C. Adipose tissue-derived human mesenchymal stem cells mediated prodrug cancer gene therapy. Cancer Res 2007; 67: 6304-6313. http://dx.doi. org/10.1158/0008-5472.CAN-06-4024

[9] ALTANER C, ALTANEROVA V. Stem cell based glioblastoma gene therapy. Neoplasma 2012; 59: 756-760. http://dx.doi. org/10.4149/neo 201295

[10] CIHOVA M, ALTANEROVA V, ALTANER C. Stem cell based cancer gene therapy. Mol Pharm 2011; 8: 1480-1487. http:// dx.doi.org/10.1021/mp200151a

[11] ALTANEROVA V, CIHOVA M, BABIC M, RYCHLY B, ONDICOVA K et al. Human adipose tissue-derived mesenchymal stem cells expressing yeast cytosinedeaminase::uracil phosphoribosyltransferase inhibit intracerebral rat glioblastoma. Int J Cancer 2012; 130: 2455-2463. http://dx.doi.org/10.1002/ ijc. 26278

[12] ALTANER C, ALTANEROVA V, CIHOVA M, ONDICOVA $\mathrm{K}$, RYCHLY B et al. Complete regression of glioblastoma by mesenchymal stem cells mediated prodrug gene therapy simulating clinical therapeutic scenario. Int J Cancer 2014; 134: 1458-1465. http://dx.doi.org/10.1002/ijc.28455

[13] THU MS, BRYANT LH, COPPOLA T, JORDAN EK, BUDDE $\mathrm{MD}$ et al. Self-assembling nanocomplexes by combining ferumoxytol, heparin and protamine for cell tracking by magnetic resonance imaging. Nat Med 2012; 18: 463-467. http://dx.doi. org/10.1038/nm.2666

[14] DELCROIX GJ, JACQUART M, LEMAIRE L, SINDJI L, FRANCONI F et al. Mesenchymal and neural stem cells labeled with HEDP-coated SPIO nanoparticles: in vitro characterization and migration potential in rat brain. Brain Res 2009; 1255: 18-31. http://dx.doi.org/10.1016/j. brainres.2008.12.013

[15] DANIELYAN L, SCHAFER R, VON AMELN-MAYERHOFER A, BERNHARD F, VERLEYSDONK S et al. Therapeutic efficacy of intranasally delivered mesenchymal stem cells in a rat model of Parkinson disease. Rejuvenation Res 2011; 14: 3-16. http://dx.doi.org/10.1089/rej.2010.1130 
[16] ClinicalTrials.gov. Use of Mesenchymal Stem Cells for Alveolar Bone Tissue Engineering for Cleft Lip and Palate Patients. 2015; Available from: https://clinicaltrials.gov/ct2/ show/NCT01932164, access date 18-03-2016.

[17] VAN VELTHOVEN CT, KAVELAARS A, VAN BEL F, HEIJNEN CJ. Nasal administration of stem cells: a promising novel route to treat neonatal ischemic brain damage. Pediatr Res 2010; 68: 419-422. http://dx.doi.org/10.1203/ pdr.0b013e3181f1c289

[18] ROGER M, CLAVREUL A, VENIER-JULIENNE MC, PASSIRANI C, SINDJI L et al. Mesenchymal stem cells as cellular vehicles for delivery of nanoparticles to brain tumors. Biomaterials 2010; 31: 8393-8401. http://dx.doi.org/10.1016/j. biomaterials.2010.07.048

[19] DANIELYAN L, SCHAFER R, VON AMELN-MAYERHOFER A, BUADZE M, GEISLER J et al. Intranasal delivery of cells to the brain. Eur J Cell Biol 2009; 88: 315-324. http:// dx.doi.org/10.1016/j.ejcb.2009.02.001

[20] REITZ M, DEMESTRE M, SEDLACIK J, MEISSNER H, FIEHLER J et al. Intranasal delivery of neural stem/progenitor cells: a noninvasive passage to target intracerebral glioma. Stem Cells Transl Med 2012; 1: 866-873. http://dx.doi.org/10.5966/ sctm.2012-0045
[21] ROSENBERG JT, SELLGREN KL, SACHI-KOCHER A, CALIXTO BEJARANO F, BAIRD MA et al. Magnetic resonance contrast and biological effects of intracellular superparamagnetic iron oxides on human mesenchymal stem cells with long-term culture and hypoxic exposure. Cytotherapy 2013; 15: 307-322. http://dx.doi.org/10.1016/j. jcyt.2012.10.013

[22] PAPADIMITRIOU N, LI S, BARRETO HENRIKSSON H. Iron sucrose-labeled human mesenchymal stem cells: in vitro multilineage capability and in vivo traceability in a lapine xenotransplantation model. Stem Cells Dev 2015; 24: 2403-2412. http://dx.doi.org/10.1089/scd.2015.0140

[23] PAPADIMITRIOU N, THORFVE A, BRANTSING C, JUNEVIK K, BARANTO A et al. Cell viability and chondrogenic differentiation capability of human mesenchymal stem cells after iron labeling with iron sucrose. Stem Cells Dev 2014; 23: 2568-2580. http://dx.doi.org/10.1089/ scd.2014.0153

[24] HAN J, KIM B, SHIN JY, RYU S, NOH M et al. Iron oxide nanoparticle-mediated development of cellular gap junction crosstalk to improve mesenchymal stem cells' therapeutic efficacy for myocardial infarction. ACS Nano 2015; 9: 2805-2819. http://dx.doi.org/10.1021/nn506732n 